\title{
Productivity of Russian Wildrye and Crested Wheat- grass and Their Effect on Prairie Soils
}

\author{
S. SMOLIAK AND J.F. DORMAAR
}

\section{Abstract}

Crested wheatgrass (Agropyron cristatum (L.) Gaertn.) and Russian wildrye (Elymus junceus Fisch.) are used extensively as seeded pastures in the Prairie Provinces of Canada. Rangeland plowed in 1954 was planted to the 2 grasses in 1955 . Herbage was harvested over a 25-year period, root weights were determined in 1977 , and soil samples were obtained in 1965 and 1978 from the 2 seeded pastures and from adjacent native rangeland from each of 3 replicates. Forage production from the seeded pastures was greatest 4 years after seeding. Averaged over all years, crested wheatgrass yielded $113 \%$ more and Russian wildrye yielded $47 \%$ more forage than did native rangeland. Total root weight in the surface $15-\mathrm{cm}$ layer of soil was greater on the native rangeland pasture than on the seeded pastures. Soils from native range pastures generally contained more organic carbon, less sodium, and had lower pH and sodium adsorption ratios than the soils from Russian wildrye pastures seeded 10 and 23 years before the soils were sampled. The organic $\mathrm{C}$ and $\mathrm{pH}$ 's of the soils obtained from crested wheatgrass pastures decreased during the 23-year period while those of soils from the native range did not change.

About 18 million ha of rangeland and 2.5 million ha of seeded pastures are utilized by the beef industry in the Prairie Provinces of Canada. It is estimated that about 1 million ha of crested wheatgrass (Agropyron cristatum (L.) Gaertn.) and 100,000 ha of Russian wildrye (Elymus junceus Fisch.) contribute to the forage supply for livestock production. Stands of the 2 introduced forages, when used to complement native range in spring and fall, have doubled livestock gains per hectare primarily by permitting increased stocking rates (Smoliak 1968, Smoliak and Slen 1974).

The loss of organic matter and $\mathrm{N}$ from soils in the Northern Great Plains through long-term wheat cropping has been documented. Such cropping over a 34-year period resulted in a loss of $35 \%$ of the $\mathrm{N}$ and $41 \%$ of the organic matter that was present in the original prairie soil, but conversion of the cropland to seeded pasture resulted in the reduction of the rate of loss of $\mathrm{N}$ and organic matter (Norum et al. 1957). Crested wheatgrass has been used to provide a permanent type of pasture and to improve the carrying capacity of grazing lands (Smoliak et al. 1967, Looman and Heinrichs 1973, Dormaar et al. 1978) on much of the abandoned, cultivated land. Early studies (Lehane and Staple 1943) showed that in addition to reducing soil erosion and increasing the grazing capacity of abandoned fields, crested wheatgrass improved the chemical and physical propertics of the soil as compared to cultivated soil. In a comparison of 40- to 49-year-old stands of crested wheatgrass with native range soils, Dormaar et al. (1978) showed that $\mathrm{pH}$ and bulk densities were higher on crested wheatgrass soils while water-stable aggregates were higher on native range soils. The greater root mass allowed for increased energy flow into the native range soil system compared with the crested wheatgrass soil system. As the crested wheatgrass stands in these studies resulted from seeding into cropland that produced several crops of cereals, it is very likely that the changes of some soil characteristics could have occurred during the cropping period although the data were

\footnotetext{
Authors are range ecologist and soil scientist, respectively, Agriculture Canada. Research Station, Lethbridge, Alberta TIJ 4B!.

Manuscript accepted April $15,1985$.
}

compared with native range soils.

Russian wildrye also appears to be capable of providing a longterm pasture with good productivity under grazing (Smoliak and Johnston 1980). However, the influence of Russian wildrye on prairie soils has not been determined. Therefore, this study was initiated to assess the changes in characteristics related to soil organic matter and the productivity of established stands of crested wheatgrass and Russian wildrye sown in 1955 on newly plowed native range.

\section{Materials and Methods}

The study was conducted at the Agriculture Canada Research Substation near Manyberries, Alberta. The vegetation of the study site is typical of the Stipa-Bouteloua faciation of the Mixed Prairie Association (Coupland 1961). The Orthic Brown Chernozemic (Aridic Ustochrept) soil is of a medium texture. Portions of native rangeland in the study area were plowed to a $10-$ to $12-\mathrm{cm}$ depth to kill the native vegetation and summer-fallowed in 1954 to accommodate seeding of introduced grasses for a sheep grazing trial (Smoliak 1968). In the spring of 1955, the prepared areas were sown to crested wheatgrass $(9.3 \mathrm{ha})$ and to Russian wildrye (10.9 ha) at $9 \mathrm{~kg} /$ ha seeding rate in $15-\mathrm{cm}$ row spacings. The study had 3 replicates. Adjacent areas of 20 ha of virgin rangeland in each of the 3 replicates completed the grazing fields. The fields were grazed by yearling ewes from 1957 through 1966 (Smoliak 1968), and by yearling steers from 1967 through 1972 (Smoliak and Slen 1974). After the grazing study was terminated, all cross fences were removed and the whole area was grazed by cows and calves from 1973 through 1980 . None of the fields was fertilized.

Herbage was harvested from 10 caged $0.89-\mathrm{m}^{2}$ areas in each pasture at the end of each grazing season from 1956 to 1980. All herbage was clipped near ground level with a hand-held power mower. The point-quadrat method was used to estimate the percentage ground cover which was reported previously (Smoliak 1968, Smoliak and Slen 1974). Root weights were determined from 5 soil plugs taken at random in each replicate in each pasture type. Plugs were $10.4 \mathrm{~cm}$ in diameter and $15 \mathrm{~cm}$ deep and were obtained with a golf-cup hole cutter in September 1977. The plugs were washed on a screen and the separated roots were dried at $100^{\circ} \mathrm{C}$ for 24 hours. Ash content of the roots was determined after ignition at $700^{\circ} \mathrm{C}$ for 4 hours. Root weights are reported on an ash-free, oven-dry basis for the $15-\mathrm{cm}$ depth.

Composite samples were obtained from the top $10 \mathrm{~cm}$ of soil in July 1965 and September 1978 from each replicate and pasture type and air-dried. The roots were screened out, after which the soil was ground to pass a $1-\mathrm{mm}$ screen.

Total organic carbon (C) of the root samples was determined by dry combustion at $900^{\circ} \mathrm{C}$ for 15 minutes with the evolved $\mathrm{CO}_{2}$ collected and weighed, total nitrogen $(N)$ was determined using a macrokjeldahl procedure, and solvent-extractable $\mathrm{C}$ was obtained by extraction in a Soxhlet apparatus for 72 hours with a mixture of ethanol-benzene (1:1). Lignin was determined as described by Deriaz (1961). Methoxyl groups were determined by a modified Zeisel technique (Tech. Assoc. of the Pulp and Paper Industry 1945). Calorific values on five bulked samples from each pasture were obtained by combustion in a Parr 1241 adiabatic oxygen 
Table 1. Precipitation and dry matter production on three pasture types, Manyberries, Alberta.

\begin{tabular}{|c|c|c|c|c|c|}
\hline \multirow[b]{2}{*}{ Year } & \multicolumn{2}{|c|}{ Precipitation (mm) } & \multicolumn{3}{|c|}{ Dry matter production $(\mathrm{kg} / \mathrm{ha})$} \\
\hline & $\begin{array}{l}\text { April to } \\
\text { July }\end{array}$ & Annual & $\begin{array}{l}\text { Native } \\
\text { range }\end{array}$ & $\begin{array}{l}\text { Crested } \\
\text { wheatgrass }\end{array}$ & $\begin{array}{l}\text { Russian } \\
\text { wildrye }\end{array}$ \\
\hline 1956 & 208 & 365 & $480 \pm 104$ & $426 \pm 93$ & $235 \pm 61$ \\
\hline 1957 & 112 & 350 & $706 \pm 178$ & $843 \pm 209$ & $790 \pm 154$ \\
\hline 1958 & 128 & 334 & $664 \pm 152$ & $1,361 \pm 240$ & $966 \pm 188$ \\
\hline 1959 & 148 & 307 & $529 \pm 120$ & $1,448 \pm 279$ & $1,020 \pm 216$ \\
\hline 1960 & 137 & 285 & $446 \pm 106$ & $702 \pm 149$ & $649 \pm 171$ \\
\hline 1961 & 78 & 215 & $272 \pm 78$ & $564 \pm 140$ & $490 \pm 101$ \\
\hline 1962 & 167 & 287 & $286 \pm 72$ & $784 \pm 131$ & $530 \pm 110$ \\
\hline 1963 & 146 & 266 & $314 \pm 74$ & $786 \pm 179$ & $527 \pm 131$ \\
\hline 1964 & 159 & 384 & $299 \pm 63$ & $804 \pm 202$ & $454 \pm 119$ \\
\hline 1965 & 419 & 600 & $547 \pm 151$ & $1,137 \pm 251$ & $1,030 \pm 296$ \\
\hline 1966 & 155 & 345 & $338 \pm 79$ & $904 \pm 237$ & $788 \pm 94$ \\
\hline 1967 & 178 & 430 & $516 \pm 129$ & $1,226 \pm 217$ & $726 \pm 109$ \\
\hline 1968 & 126 & 320 & $574 \pm 147$ & $916 \pm 168$ & $682 \pm 164$ \\
\hline 1969 & 100 & 243 & $319 \pm 93$ & $761 \pm 133$ & $588 \pm 120$ \\
\hline 1970 & 219 & 352 & $238 \pm 71$ & $863 \pm 234$ & $475 \pm 104$ \\
\hline 1971 & 157 & 316 & $245 \pm 62$ & $700 \pm 184$ & $424 \pm 86$ \\
\hline 1972 & 126 & 334 & $178 \pm 43$ & $610 \pm 134$ & $399 \pm 95$ \\
\hline 1973 & 98 & 219 & $188 \pm 51$ & $522 \pm 149$ & $261 \pm 34$ \\
\hline 1974 & 215 & 382 & $476 \pm 127$ & $824 \pm 197$ & $544 \pm 102$ \\
\hline 1975 & 295 & 572 & $593 \pm 135$ & $1,295 \pm 262$ & $758 \pm 142$ \\
\hline 1976 & 175 & 300 & $439 \pm 107$ & $1,158 \pm 214$ & $690 \pm 156$ \\
\hline 1977 & 114 & 286 & $274 \pm 71$ & $520 \pm 145$ & $358 \pm 66$ \\
\hline 1978 & 220 & 513 & $493 \pm 121$ & $762 \pm 87$ & $610 \pm 139$ \\
\hline 1979 & 168 & 343 & $421 \pm 104$ & $1,088 \pm 248$ & $508 \pm 78$ \\
\hline 1980 & 162 & 334 & $416 \pm 98$ & $785 \pm 186$ & $523 \pm 107$ \\
\hline \multicolumn{6}{|l|}{ Mean } \\
\hline-25 years & 168 & 347 & 410 & 872 & 601 \\
\hline 52 years & 164 & 324 & & & \\
\hline
\end{tabular}

bomb calorimeter. All values are expressed on a dry, ash-free basis.

Total organic $\mathrm{C}$ of the soil samples was determined by dry combustion at $900^{\circ} \mathrm{C}$ for 15 minutes with the evolved $\mathrm{CO}_{2}$ collected and weighed, while total $\mathrm{N}$ was determined using a macrokieldhl procedure. Soil $\mathrm{pH}$ was measured in $0.01 \mathrm{M} \mathrm{CaCl}_{2}$. Since Russian wildrye is a useful grass on saline soils, it was deemed useful for future reference to obtain baseline data of several parameters indicative of saline soils, such as $\mathrm{pH}$, electrical conductivity (EC), sodium adsorption ratio (SAR), and the water soluble $\mathrm{Na}, \mathrm{Ca}$, and Mg contents (U.S. Sal. Lab. Staff 1954, Rhodes 1982).

An analysis of variance test with years as a split plot was used to determine if any significant differences existed between the year means. Duncan's multiple range test at the $0.05 \%$ level was used to determine significant differences among the 3 pasture types.

\section{Results and Discussion}

Dry matter production of the native range and the 2 seeded pastures was measured over a 25-year period (Table I). Crested wheatgrass pastures produced an average of about $113 \%$ more forage than did the native range pastures, while Russian wildrye pastures produced about $47 \%$ more. Although the peak forage production of crested wheatgrass was reached 4 years after seeding, both seeded pastures responded to seasonal precipitation as did the native range. Mean precipitation during the 25 -year period was greater than the long-term averages. The higher production of herbage on seeded pastures, as compared to native range pastures, could be a result of a greater release of $N$. Coupland (1973) has suggested that the loosening of the soil and its greater exposure to sunlight increases the rate of decomposition of organic matter and this consequently increases the supply of $\mathrm{N}$.

Total root weight in the surface $15-\mathrm{cm}$ layer of soil was greater on the native range pasture than on the seeded pastures (Table 2). The greater root weight also resulted in a higher $\mathrm{kCal} / \mathrm{m}^{2}$ of the native range soil. There were no differences in the total $\mathrm{C}$ content
Table 2. Characteristics of root material of native range, crested wheatgrass and and Russian wildrye sod.

\begin{tabular}{lccc}
\hline \hline Characteristic measured & Native & $\begin{array}{c}\text { Crested } \\
\text { wheatgrass }\end{array}$ & $\begin{array}{l}\text { Russian } \\
\text { wildrye }\end{array}$ \\
\hline Total C (\%) & $49.8 \mathrm{a}^{1}$ & $49.7 \mathrm{a}$ & $47.1 \mathrm{a}$ \\
Total N (\%) & $2.3 \mathrm{~b}$ & $2.7 \mathrm{a}$ & $2.2 \mathrm{~b}$ \\
Solvent extractable C (\% of & & & \\
$\quad$ total C) & $16.0 \mathrm{~b}$ & $23.3 \mathrm{a}$ & $17.4 \mathrm{~b}$ \\
Lignin (\%) & $16.4 \mathrm{a}$ & $16.0 \mathrm{a}$ & $13.2 \mathrm{~b}$ \\
OCH $(\mathrm{meq} / \mathrm{g}$ of O.M.) & $3.0 \mathrm{~b}$ & $3.4 \mathrm{a}$ & $2.9 \mathrm{~b}$ \\
Calorific value (Cal/g) & $4866 \mathrm{~b}$ & $5019 \mathrm{a}$ & $4585 \mathrm{c}$ \\
Root weight to $15-\mathrm{cm}$ depth & & & \\
$\quad\left(\mathrm{g} / \mathrm{m}^{2}\right)$ & $1472 \mathrm{a}$ & $1150 \mathrm{~b}$ & $1165 \mathrm{~b}$ \\
$\mathrm{kCa} / \mathrm{m}^{2}$ & $7160 \mathrm{a}$ & $5771 \mathrm{~b}$ & $5340 \mathrm{~b}$ \\
\hline
\end{tabular}

I Means within rows followed by the same letter are not significantly different $(P<0.05)$ according to Duncan's multiple range tcst.

but the crested wheatgrass roots contained more total $\mathrm{N}$, solventextractable $\mathrm{C}$, and methoxyl group, and had a higher calorific value than the roots of the native range or Russian wildrye. The roots of native range and crested wheatgrass contained more lignin than those of the Russian wildrye.

Soil from the Russian wildrye pastures contained less organic $\mathrm{C}$ in 1965 and 1978, less total $\mathrm{N}$ in 1978, and had a lower pH in 1978 than the native range soils (Table 3). Soil from the crested wheatgrass pastures contained less organic $\mathrm{C}$ and had a lower $\mathrm{pH}$ in 1978 than did the native range soils.

The soils from the Russian wildrye pastures also had higher SAR values and contained more water extractable Na than did the soils from the native range and crestcd wheatgrass pastures (Table 3). From 1965 to 1978 the values for EC, SAR, and water soluble $\mathrm{Na}$, and $\mathrm{Ca}+\mathrm{Mg}$ decreased in all pastures. These variables are used 
Table 3. Some characteristics of soil from native range, crested wheatgrass and Russian wildrye pastures (average of 3 samples).

\begin{tabular}{|c|c|c|c|}
\hline Characteristic measured & Native & $\begin{array}{c}\text { Crested } \\
\text { wheatgrass }\end{array}$ & $\begin{array}{l}\text { Russian } \\
\text { wild rye }\end{array}$ \\
\hline $\begin{array}{c}\text { Total organic C (\%) } \\
1965 \\
1978\end{array}$ & $\begin{array}{l}1.40 \mathrm{a}^{1} \\
1.42 \mathrm{a}^{2}\end{array}$ & $\begin{array}{l}1.36 \mathrm{a} \\
1.26 \mathrm{~b}\end{array}$ & $\begin{array}{l}1.27 \mathrm{~b} \\
1.21 \mathrm{~b}\end{array}$ \\
\hline $\begin{array}{c}\text { Total N }(\%) \\
1965 \\
1978\end{array}$ & $\begin{array}{l}0.14 a \\
0.14 a\end{array}$ & $\begin{array}{l}0.14 a \\
0.13 a\end{array}$ & $\begin{array}{l}0.13 a \\
0.12 b\end{array}$ \\
\hline $\begin{array}{c}\text { C/N ratio } \\
1965 \\
1978\end{array}$ & $\begin{array}{l}10.0 \mathrm{a} \\
10.1 \mathrm{a}\end{array}$ & $\begin{array}{l}9.7 \mathrm{a} \\
9.7 \mathrm{a}\end{array}$ & $\begin{array}{r}9.8 \mathrm{a} \\
10.1 \mathrm{a}\end{array}$ \\
\hline $\begin{array}{r}\mathrm{pH} \mathrm{CaCl} \\
1965 \\
1978\end{array}$ & $\begin{array}{l}6.8 \mathrm{a} \\
6.8 \mathrm{a}\end{array}$ & $\begin{array}{l}6.7 a \\
6.6 b\end{array}$ & $\begin{array}{l}6.6 \mathrm{a} \\
6.2 \mathrm{c}^{* *}\end{array}$ \\
\hline $\begin{array}{c}\mathrm{EC}(\mathrm{dS} / \mathrm{m}) \\
1965 \\
1978\end{array}$ & $\begin{array}{l}1.03 \mathrm{a} \\
0.47 \mathrm{a}^{* *}\end{array}$ & $\begin{array}{l}0.86 \mathrm{a} \\
0.39 \mathrm{a}^{* *}\end{array}$ & $\begin{array}{l}1.19 \mathrm{a} \\
0.43 \mathrm{a}^{* *}\end{array}$ \\
\hline $\begin{array}{l}\text { SAR } \\
1965 \\
1978\end{array}$ & $\begin{array}{l}0.60 \mathrm{~b} \\
0.29 \mathrm{~b}\end{array}$ & $\begin{array}{l}0.51 \mathrm{~b} \\
0.36 \mathrm{~b}\end{array}$ & $\begin{array}{l}0.83 \mathrm{a} \\
0.47 \mathrm{a}\end{array}$ \\
\hline $\begin{array}{c}\mathrm{Na}(\mathrm{meq} / \text { liter }) \\
1965 \\
1978\end{array}$ & $\begin{array}{l}1.3 b \\
0.4 b^{* *}\end{array}$ & $\begin{array}{l}1.0 b \\
0.5 b^{* *}\end{array}$ & $\begin{array}{l}2.0 \mathrm{a} \\
0.6 \mathrm{a}^{* *}\end{array}$ \\
\hline $\begin{array}{c}\mathrm{Ca}+\underset{1965}{\mathrm{Mg}(\mathrm{Meq} / \text { liter })} \\
1978\end{array}$ & $\begin{array}{l}9.4 \mathrm{a} \\
4.0 \mathrm{a}^{* * *}\end{array}$ & $\begin{array}{l}8.3 \mathrm{a} \\
3.3 \mathrm{a}^{* *}\end{array}$ & $\begin{array}{l}10.2 \mathrm{a} \\
2.9 \mathrm{a}^{* *}\end{array}$ \\
\hline
\end{tabular}

I Means within rows followed by the same letter are not significantly different $(P<0.05)$ according to Duncan's multiple range test.

**Significantly different $(P<0.01)$ from value in 1965 .

to measure soil salinity but the change during the 13 years is thought to be in response to the differences in precipitation during the 2 sampling years. Bowman et al. (1984) have shown that changes in $\mathrm{Na}$ concentrations in soils supporting Russian wildrye were related to moisture availability.

The results of this study show that, like crested wheatgrass, Russian wildrye is adapted to the study area. The root weight of Russian wildrye in the top $15 \mathrm{~cm}$ of soil was similar to that of crested wheatgrass. There was some invasion by native grasses into the Russian wildrye pastures, but none into the crested wheatgrass pastures.

The Russian wildrye root material had a lower lignin content than either the native range or crested wheatgrass root material and lower root weight $/ \mathrm{m}^{2}$ than the native range sod. It is likely that the lower lignin content of the Russian wildrye root material allowed for a faster turnover initially. In fact, it may have even primed the native organic matter in the process. Plowing of the soil would have accelerated the breakdown of the organic matter as well. However, as the organic matter level came to a new equilibrium, soil-nutrient cycling would be lower than in crested wheatgrass sod. In 10 years, Russian wildrye reduced $(P<0.05)$ the amount of organic $C$ in the soil and, in 23 years, the amount of total N. Reduced amounts of organic $C$ were observed in soils on the crested wheatgrass sites after 23 years. Thus, while both introduced grass species did deplete soil nutrients, the reduction was not as great as that reported under cereal cropping (Lehane and Staple 1943). Although the nutritional requirements of the 2 introduced grasses were not determined, it may well be that they are greater than those of native rangeland grasses, which have evolved on soils with low nutrient levels, and that additional nutrients could be provided through the application of fertilizers.

\section{Literature Cited}

Bowman, R.A., D.M. Mueller, and W.J. McGinnies. 1984. Soil-plant factors in early browning of Russian wildrye on Natrustoll Soils. J. Range Manage. 37:225-228.

Coupland, R.T. 1961. A reconsideration of grassland classification in the Northern Great Plains of North America. J. Ecol. 53:475-507.

Coupland, R.T. 1973. Producers: I. Dynamics of above-ground standing crop. Univ. Saskatchewan, Saskatoon, Sask., Matador Proj. Tech. Rep. No. 27.

Deriaz, R.E. 1961. Routine analysis of carbohydrates and lignin in herbage. J. Sci. Food Agr. 12:152-160.

Dormaar, J.F., A. Johnston, and S. Smoliak. 1978. Long-term soil changes associated with seeded stands of crested wheatgrass in southwestern Alberta, Canada. Proc. 1st Int. Rangeland Congr. 1:623-625.

Lehane, J.J., and W.J. Staple. 1943. The effect of crested wheatgrass on some physical and chemical characteristics of the soil. Sci. Agr. 23:509-517.

Looman, J., and D.H. Heinrichs. 1973. Stability of crested wheatgrass pastures under long-term pasture use. Can. J. Plant Sci. 53:501-506.

Norum, E.B., B.A. Krantz, and H.J. Haas. 1957. The northern Great Plains. p. 494-505. In: Soil. The Yearbook of Agriculture. USDA, U.S. Government Printing Office, Washington, D.C.

Rhodes, J.D. 1982. Soluble salts. In: A.L. Page (ed.) Methods of soil analysis. Part 2. Chemical and microbiological properties. Agron. 9:167179. Amer. Soc. Agron., Madison, Wis.

Smoliak, S. 1968. Grazing studies on native range. crested wheatgrass, and Russian wildrye pastures. J. Range Manage. 21:44-50.

Smoliak, S., and A. Johnston. 1980. Russian wildrye lengthens the grazing season. Rangelands. 2:249-250.

Smoliak, S., A. Johnston, and L.E. Lutwick. 1967. Productivity and durability of crested wheatgrass in southeastern Alberta. Can. J. Plant Sci. 47:539-548.

Smoliak, S., and S.B. Slen. 1974. Beef production on native range, crested wheatgrass, and Russian wildrye pastures. J. Range Manage. 27:433-436.

Technical Association of the Pulp and Paper Industry. 1945. Methoxyl groups in wood. TAPPI T2 m-43, New York, N.Y.

U.S. Salinity Laboratory Staff. 1954. Diagnosis a nd improvement of saline and alkali soils. Agr. Handb. No. 60. USDA. U.S. Government Printing Office, Washington, D.C. 